\title{
ShenFu Preparation Protects AML12 Cells Against Palmitic Acid-Induced Injury Through Inhibition of Both JNK/Nox4 and JNK/NFkB Pathways
}

\author{
Jia-Fu Jia,b Wan-Zhen Jiao ${ }^{c}$ Yan Cheng ${ }^{d}$ Hua Yane Fan Su ${ }^{b}$ Li-Li Chie \\ aShandong University of Traditional Chinese Medicine, Jinan, ${ }^{\mathrm{b} D e p a r t m e n t}$ of Anesthesiology, \\ Affiliated Hospital of Shandong University of Traditional Chinese Medicine, Jinan, 'Department of \\ Ophthalmology, Shandong Provincial Hospital Affiliated to Shandong University, Jinan, dDepartment \\ of Cardiology, Affiliated Hospital of Shandong University of Traditional Chinese Medicine, Jinan, \\ eDepartment of Gastroenterology, Affiliated Hospital of Shandong University of Traditional Chinese \\ Medicine, Jinan, China
}

\section{Key Words}

Nonalcoholic steatohepatitis - ShenFu preparation - Palmitic acid - Nox4 - Mitochondrial dysfunction $\cdot$ Cytokines $\cdot$ Apoptosis

\begin{abstract}
Background/Aims: Nonalcoholic steatohepatitis includes steatosis along with liver inflammation, hepatocyte injury and fibrosis. In this study, we investigated the protective role and the potential mechanisms of a traditional Chinese medicine ShenFu (SF) preparation in an in vitro hepatic steatosis model. Methods: In palmitic acid (PA)-induced murine hepatic AML12 cell injury, effects of SF preparation on cellular apoptosis and intracellular triglyceride (iTG) level were assessed using TUNEL and TG Colorimetric Assay. Reactive oxygen species (ROS) and mitochondrial membrane potential (MMP) levels were measured using DCF and JC-1 assay. Cytokine levels were evaluated using ELISA assay. Immunoblot was used to compare the activation level of c-Jun N terminal kinase (JNK), NADPH oxidase (Nox4), and NFKB pathways. Results: Addition of SF preparation prevented PA-mediated increase of apoptosis and iTG as well as IL-8 and IL-6. In PA-treated cell, SF preparation reduced the level of Nox4 and ROS, while increasing the level of MMP and the expression of manganese superoxide dismutase (MnSOD) and catalase, indicating emendation of mitochondrial dysfunction. Nox4 inhibitor GKT137381 prevented PA-induced increase of ROS and apoptosis, while decreasing iTG slightly and not influencing the level of IL-8 and IL-6. SF preparation prevented PA-induced upregulation of phospho-JNK. JNK inhibitor SP600125 prevented PA-mediated increase of Nox4, IL-8, IL-6 and iTG. Nuclear translocation of NFkB/p65 was detected in PA-treated cells, which was prevented by SF preparation. An IKB degradation inhibitor, BAY11-7082, prevented PA-induced increase J.-F. Ji and W.-Z. Jiao contributed equally to this work.

Li-Li Chi

and Fan Su

\section{KARGER}




\section{Cellular Physiology Cell Physiol Biochem 2018;45:1617-1630 \\ \begin{tabular}{ll|l} 
and Biochemistry & $\begin{array}{l}\text { DOI: 10.1159/000487728 } \\
\text { Published online: rebruary 26, } 2018\end{array}$ & $\begin{array}{l}\text { 2018 The Author(s). Published by S. Karger AG, Basel } \\
\text { www.karger.com/cpb }\end{array}$ \\
\cline { 2 - 3 }
\end{tabular} \\ Ji et al.: The Protective Role of ShenFu Preparation in PA-Induced AML12 Cell Injury}

of IL-8 and IL- 6 as well as ITG, whereas it only decreased ROS levels slightly and showed no influence on cellular apoptosis. Conclusion: SF preparation shows a beneficial role in prevention of hepatocyte injury by attenuating oxidative stress and cytokines production at least partially through inhibition of JNK/Nox4 and JNK/NFKB pathway, respectively.

(C) 2018 The Author(s)

Published by S. Karger AG, Basel

\section{Introduction}

Nonalcoholic steatohepatitis (NASH), a common liver disease throughout the world, is characterized by micro/macro-vesicular steatosis along with liver inflammation, hepatocyte injury and fibrosis [1]. Nevertheless, the pathogenesis of NASH is still elusive. Accumulation of lipids, particularly triacylglycerol, in hepatocytes is a key pathogenic event in the development of NASH which causes lipid toxicity, inducing hepatic injury and promoting inflammation [1 - 3]. In hepatocytes, an important source for triacylglycerol synthesis is circulating free fatty acids (FFA) [4]. Palmitic acid (PA) makes up a majority of FFA in triacylglycerol [5]. In NASH patients, elevated PA levels are observed $[4,5]$. Aberrant apoptosis is a common feature of NASH and is related to the progression of liver fibrosis [6 - 8]. It was reported that in NASH, excessive hepatocyte apoptosis stimulates the production of several pro-inflammatory cytokines such as IL-1, IL-6, IL-8 and TNF $\alpha$ both in innate immune cells and hepatocytes inducing unresolved hepatocytic inflammation [7]. Mitochondrial dysfunction involves the regulation of apoptosis by releasing some mitochondrial intermembrane space proteins such as cytochrome c, endonuclease G, and apoptosis-inducing factor [9]. Subsequently, cytosolic cytochrome c activates a multiprotein complex, which in turn results in cleavage of procaspase 9 and downstream effector caspase 3, leading to cell death [9]. Mitochondrial damage was found both in in vitro hepatocyte injury and in murine hepatotoxicity fibrosis models $[10,11]$. It is important to reveal the molecular mechanisms of hepatocyte injury in NASH and find effective drugs to prevent and/or treat it.

In this study, we investigated the protective role and the potential mechanisms of ShenFu (SF) preparation in PA-induced murine hepatic AML12 cell injury, an in vitro hepatic steatosis model [12]. SF preparation, a modern Chinese medicine preparation, was developed from a traditional formulation "ShenFu decoction" that consists of red ginseng (steamed roots of Panax ginseng) and aconite (processed lateral roots of Aconitum carmichaeli) [13]. $\mathrm{SF}$ preparation is prepared by using countercurrent extraction and macroporous resin adsorption chromatography. In China, SF preparation is commonly used in clinical practice for the treatment of septic shock and ischemic diseases and has been shown to have a beneficial role against ischemic-reperfusion injuries on many organs including the brain, spinal cord, kidneys, intestines, liver and heart $[14,15]$. Recently, it was reported that SF preparation has obviously protective effects on cardiomyocytes against apoptosis by inhibition of downregulation of $\mathrm{Bcl}-2$ and sequential activation of caspase 3 [15]. Here, we provide key evidence in PA-treated AML12 cell, i) induction of mitochondrial NADPH oxidase (Nox4) by overactivated JNK signaling leading to mitochondrial dysfunction and oxidative stress, being responsible for induction of apoptosis; ii) JNK-mediated nuclear translocation of NFKB/p65 and its relation to overproduction of intracellular triglyceride (iTG) and cytokines IL-8 and IL-6; and iii) SF preparation protecting AML12 cells from PA-induced injury at least partially through inhibition of both JNK/Nox4 and JNK/NFKB pathways.

\section{Materials and Methods}

\section{Cell culture and treatment}

AML12, a mouse hepatocyte cell line, was cultured at $37^{\circ} \mathrm{C}$ with DMEM/F-12 medium (Gibco, Grand Island, NY, USA) supplemented with 10\% FBS (Gibco), 1 x ITS (insulin/transferrin/selenium, Gibco), and 40 $\mathrm{ng} / \mathrm{ml}$ dexamethasone (Sigma-Aldrich, St. Louis, MO, USA). Cultured cells were treated with different doses of bovine serum albumin (BSA)-complexed palmitic acid (PA, 0.1, 0.2, $0.4 \mathrm{mM}$ ) for various time periods 


\section{Cellular Physiology Cell Physiol Biochem 2018;45:1617-1630 \begin{tabular}{l|l|l|l} 
DOI: 10.1159/000487728 & 2018 The Author(s). Published by S. Karger AG, Basel \\
and Biochemistry & Published online: February 26, 2018 www.karger.com/cpb
\end{tabular}

$(12,24,48$ h). PA was made as previously reported [10 - 12]. Palmitic acid powder (Sigma-Aldrich) was then added to a $10 \%$ solution of fatty acid free BSA and dissolved to yield an $8 \mathrm{mM}$ solution of palmitic acid complexed to BSA.

To assess the role of ShenFu (SF) preparation on PA-induced hepatocyte injury, AML12 cells were pretreated for $2 \mathrm{~h}$ with SF preparation (Ya'an Sanjiu Pharmaceutical Co., Ltd., Sichuan province, China), followed by $0.4 \mathrm{mM}$ PA for $24 \mathrm{~h}$ in the presence of SF preparation. Three concentrations of SF preparation were used; Low (L, $25 \mu \mathrm{l} / \mathrm{ml})$, Moderate $(\mathrm{M}, 50 \mu \mathrm{l} / \mathrm{ml})$ and High $(\mathrm{H}, 100 \mu \mathrm{l} / \mathrm{ml})$, respectively.

A selective inhibitor of JNK, SP600125 (final concentration $10 \mu \mathrm{M}$, sc-200635; Dallas, Santa Cruz, TX, USA), a novel Nox1/Nox4 inhibitor, GKT137831 (final concentration 0.2, 1 and $5 \mu \mathrm{M}$; No17764, Cayman Chemical, Ann Arbor, Michigan, USA), an IKB degradation inhibitor, BAY11-7082 (final concentration 10 $\mu \mathrm{M}$; ab141228, Abcam, Cambridge, MA, USA), mitochondrial respiration chain inhibitor, antimycin A (AMA, final concentration $2.5 \mu \mathrm{M} ;$ A8674, Sigma-Aldrich), and ROS scavenger, butylated hydroxyanisole (BHA, final concentration 25, 50, and $100 \mu \mathrm{M}$; W218308, Sigma-Aldrich) were used in this study.

TUNEL assay

Apoptotic cells were revealed using DeadEnd ${ }^{\mathrm{TM}}$ Fluorometric TUNEL System (Promega, Madison, WI, USA). Cells were then cultured on coverslips and fixed in 4\% PFA/PBS for $25 \mathrm{~min}$ at $4^{\circ} \mathrm{C}$, followed by permeabilization in $0.25 \%$ TritonX-100/PBS for $5 \mathrm{~min}$ at room temperature. Afterwards, $100 \mu \mathrm{l}$ of Equilibration Buffer was added and incubated for $10 \mathrm{~min}$. The fragmented DNA of the apoptotic cells was labeled at $37^{\circ} \mathrm{C}$ for $1 \mathrm{~h}$ by addition of $50 \mu \mathrm{l}$ of TdT reaction mix containing fluorescein-12-dUTP and the Recombinant Terminal Deoxynucleotidyl Transferase (rTdT) in a dark humidified chamber. The reaction was terminated by immersing the coverslips in 2 x SSC for 15 min. After 3 washes with PBS, coverslips were mounted using anti-fade mounting media containing DAPI (Invitrogen, Grand Island, NY, USA). Apoptotic cells labeled by the fluorescein-12-dUTP were directly visualized by fluorescence microscopy (Zeiss, Oberkochen, Germany). DAPI-stained nuclei indicate the total cell number. Twenty different fields of each sample were analyzed and the representative images were provided. The percentage of apoptotic cells relative to total cells was calculated and compared.

\section{Triglyceride Colorimetric Assay}

The intracellular triglyceride (iTG) level was assessed using a Triglyceride Colorimetric Assay Kit according to the manufacturer's procedure (Cayman Chemical). Cultured cells $\left(1 \times 10^{7}\right.$ each group) were collected using a rubber policeman, and then centrifuged at 1, $000 \mathrm{rpm}$ for $5 \mathrm{~min}$. The cell pellet was resuspended in $1 \mathrm{ml}$ of cold diluted Standard Diluent, and sonicated 20 times at one second bursts. Afterwards, the supernatant was obtained by centrifugation at $10,000 \mathrm{x} \mathrm{g}$ for $10 \mathrm{~min}$ at $4^{\circ} \mathrm{C} .10 \mu \mathrm{l}$ of standard or sample $(10 \mu \mathrm{g})$ was added to the designed wells in 96-well plate. Duplicate wells were used for each sample. The two wells containing Standard Diluent alone were used as the blank or background control. Thereafter, $150 \mu \mathrm{l}$ of diluted Enzyme Mixture solution was added to each well. The plates were incubated for $15 \mathrm{~min}$ at room temperature followed by measurement of absorbance at $520 \mathrm{~nm}$ using a plate reader. The amount $(\mu \mathrm{g})$ of iTG per $1 \mathrm{mg}$ cellular protein was calculated. Three independent experiments were performed.

\section{Enzyme-linked immunosorbent assay (ELISA)}

Mouse IL-8, IL-1 $\beta$, IL- 6 and TNF $\alpha$ were measured in cell-free culture supernatants by highly specific ELISA kits according to the manufacturer's protocol (Bio-Source \& ThermoFisher Scientific, Grand Island, NY, USA). For cytokines detection assay, AML12 cells cultured in 1\% FBS were treated, and then the media was collected by centrifugation at 2, $500 \mathrm{rpm}$ for $10 \mathrm{~min}$ at $4^{\circ} \mathrm{C} .10 \mu \mathrm{l}$ of supernatant was used to run ELISA assay. Three independent experiments and duplicate wells were performed. The value was read at OD450 $\mathrm{nm}$ and the value from the blank control was subtracted. The concentration of cytokines in samples was calculated based on the standard curve.

\section{Immunoblot assay}

For total cellular protein extraction, cells were lysed in 1X radioimmunoprecipitation (RIPA) buffer (20 mM Tris-HCl pH7.5, $150 \mathrm{mM} \mathrm{NaCl}, 1 \mathrm{mM}$ EGTA, 1\% NP-40, 1\% SDS, $2.5 \mathrm{mM}$ sodium pyrophosphate, $1 \mathrm{mM} \beta$-glycerophosphate, $1 \mathrm{mM} \mathrm{Na}_{3} \mathrm{VO}_{4}$, and $1 \mu \mathrm{g} / \mathrm{ml}$ leupeptin) supplemented with $1 \mathrm{mM}$ PMSF (Sigma- 


\section{Cellular Physiology Cell Physiol Biochem 2018;45:1617-1630 \begin{tabular}{ll|l} 
DOI: 10.1159/000487728 & (0) 2018 The Author(s). Published by S. Karger AG, Basel \\
www.karger.com/cpb
\end{tabular} \\ Ji et al.: The Protective Role of ShenFu Preparation in PA-Induced AML12 Cell Injury}

Aldrich). Cytosolic, Mitochondrial and Nuclear containing fractions were isolated using a Standard Cell Fractionation Kit (ab109719, Abcam) according to the manufacturer's protocol. A BCA Protein Assay (ThermoFisher Scientific) was used for protein quantification. In total, $75 \mu \mathrm{g}$ of protein was loaded for 7.5 - $12.5 \%$ sodium dodecyl sulfate polyacrylamide gel electrophoresis (SDS-PAGE). The protein was then transferred to a Nitrocellulose Transfer Membrane (Abcam). 5\% BSA prepared in 0.05\% Tween-20 Tris-buffered saline (TTBS) was used for reducing non-specific antibody binding. The following primary antibodies were applied at $4{ }^{\circ} \mathrm{C}$ for overnight: rabbit anti-caspase3 (ab32351, 1:1,000, Abcam), rabbit antiBcl-2 (ab59348, $1:$ 1, 000), rabbit anti-Nox4 (ABC271, 1 : 250, EMD Millipore, Burlington, MA, USA), rabbit anti-Nox1 (SAB2108601, 1: 800, Sigma-Aldrich), rabbit anti-CoxIV (ab16050, $1: 200$ ), mouse anti-Histone H3 (ab182926, $1:$ 1, 000), rabbit anti-ATP5A (ab176569, $1:$ 750), rabbit anti-c-Jun N terminal kinase (JNK) (\#9252, 1 : 1, 000, Cell Signaling Technology), mouse anti-phospho-JNK (Thr183/Tyr185) (\#9255, $1: 1$,

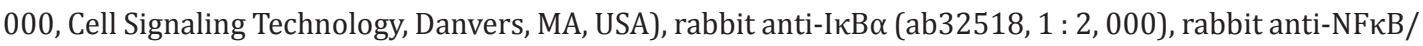
p65 (\#8242, $1:$ 1, 000, Cell Signaling Technology), rabbit anti-manganese superoxide dismutase (MnSOD) (ab13533, $1:$ 1, 000), rabbit anti-catalase (ab16731, $1: 500)$, and mouse anti-GAPDH (ab8245, $1: 5$, 000). After 5 min x 3 washes in TTBS, membranes were incubated with HRP-conjugated goat anti-rabbit (\#31460, 1 : 10, 000, ThermoFisher) or goat anti-mouse IgG (\#31430, 1: 10, 000, ThermoFisher) for $1 \mathrm{~h}$. The blots were developed using ECL chemiluminescence reagent (Pierce). The intensity of specific band was quantitated using Fiji-ImageJ-Win64 (Version 1.51s, NIH, USA).

\section{JC-1 assay: MMP level detection}

Cellular mitochondrial membrane potential (MMP) level was determined by using JC-1 MMP Assay Kit according to the manufacturer's instructions (Abcam). $2.5 \times 10^{5}$ cells were resuspended in $1 \times$ Dilution Buffer. JC-1 was added at the concentration of $2.5 \mu \mathrm{M}$, and incubated for $30 \mathrm{~min}$ at $37^{\circ} \mathrm{C}$. Cells were washed once with $1 \times$ Dilution Buffer and resuspended in 1 x Dilution Buffer. The plate was read at Ex475 \pm 20 $\mathrm{nm} /$ Em530 $\pm 15 \mathrm{~nm}$ and $590 \pm 17.5 \mathrm{~nm}$. The signal at $590 \mathrm{~nm}$ (J-aggregate) and $520 \mathrm{~nm}$ (J-monomer) was recorded by using the Fluorescence plate reader (PerSeptive Biosystems, Cambridge, MA, USA). Data is expressed as the ratio of J-aggregate to J-monomer.

\section{DCF assay: ROS level detection}

Cellular reactive oxygen species (ROS) level was quantitatively measured using DCFDA Cellular ROS Detection Assay Kit according to the manufacturer's guideline (Abcam). $2 \times 10^{5}$ cells were plated in a 96-well plate and treated as the indicated. Following PBS washes, DCFDA was added at the concentration of $20 \mu \mathrm{M}$ in serum free media, and incubated at $37^{\circ} \mathrm{C}$ for $30 \mathrm{~min}$. The cells were washed with phenol red-free DMEM media, and DCF fluorescence resulting from ROS-oxidized DCFDA was detected at $529 \mathrm{~nm}$ by using plate reader (PerSeptive Biosystems). Data are presented as fold change over control.

\section{FFA uptake assay}

AML12 cells were treated for $24 \mathrm{~h}$ with SF preparation. Then, $5 \times 10^{4}$ cells were plated on 96 -well plate for $6 \mathrm{~h}$ in serum-free medium containing SF preparation. Two wells with growth medium only were used as blank wells for data normalization. $100 \mu \mathrm{l}$ of 1 x FITC-conjugated FFA (ab176768, Abcam) was added and incubated for $30 \mathrm{~min}$. The fluorescence signal was measured with a fluorescence microplate reader at Ex $485 \mathrm{~nm}$ and $\mathrm{Em} 515 \mathrm{~nm}$.

\section{Statistical analysis}

Data are shown as mean \pm SD. Statistical analysis was performed by using One-Way or Two-Way ANOVA for comparing multiple groups (GraphPad Prism 4.0, USA). A p $<0.05$ was considered significant.

\section{Results}

Injury of AML12 cells induced by PA is ameliorated by ShenFu preparation treatment

Firstly, we established an in vitro model of hepatocyte injury induced in murine hepatic AML12 cells by applying three doses of PA for $24 \mathrm{~h}$. In comparison with non-treated cells, TUNEL assay shows a dose-dependent increase of the percentage of apoptotic cells after PA 


\section{Cellular Physiology and Biochemistry

Fig. 1. Cellular apoptosis and intracellular triglyceride levels are increased in PA-treated AML12 cells. AML12 cells were treated for $24 \mathrm{~h}$ with three different concentrations of PA $(0.1,0.2$, and 0.4 $\mathrm{mM})$, respectively. Non-treated cells were used as controls (CTL). (A) The effect of PA on cellular apoptosis was evaluated using TUNEL assay. Apoptotic cells were indicated by red color (Arrow). Magnification: 20x. (B) The percentage of apoptotic cells relative to total cells marked by blue nuclear stain was calculated, and compared between different groups. The data is presented as the means \pm S.D. $N=$ 3. ${ }^{*} \mathrm{P}<0.05$ vs. CTL, ${ }^{*} \mathrm{P}<0.05$ vs. $\mathrm{PA}(0.1 \mu \mathrm{M})$,

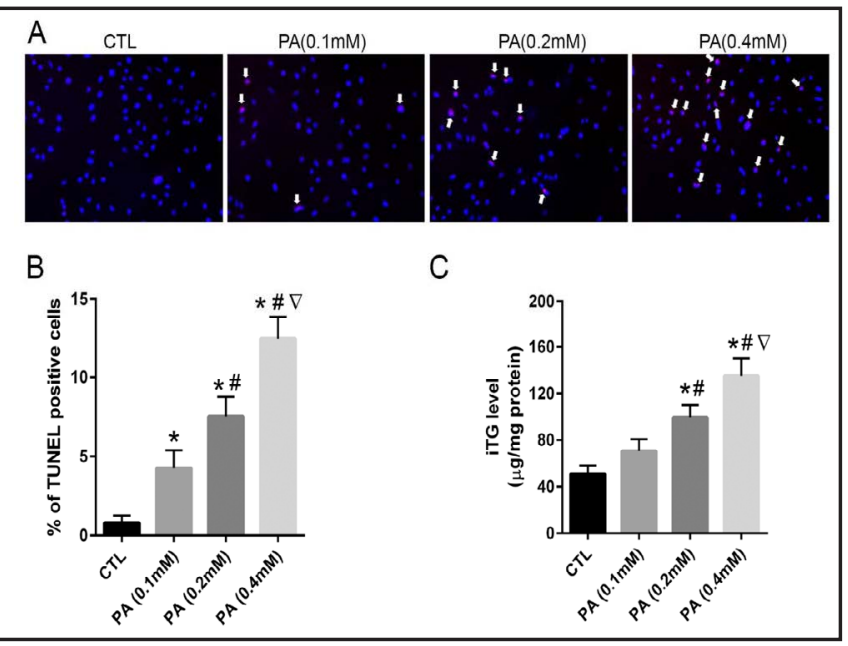
${ }^{\Delta} \mathrm{P}<0.05$ vs. $\mathrm{PA}(0.2 \mu \mathrm{M})$. (C) Intracellular

triglyceride (iTG) levels were measured using Triglyceride Colorimetric Assay. The data is presented as the means \pm S.D. $N=3 .{ }^{*} \mathrm{P}<0.05$ vs. CTL, ${ }^{\#} \mathrm{P}<0.05$ vs. $\mathrm{PA}(0.1 \mu \mathrm{M}),{ }^{\Delta} \mathrm{P}<0.05$ vs. $\mathrm{PA}(0.2 \mu \mathrm{M})$.

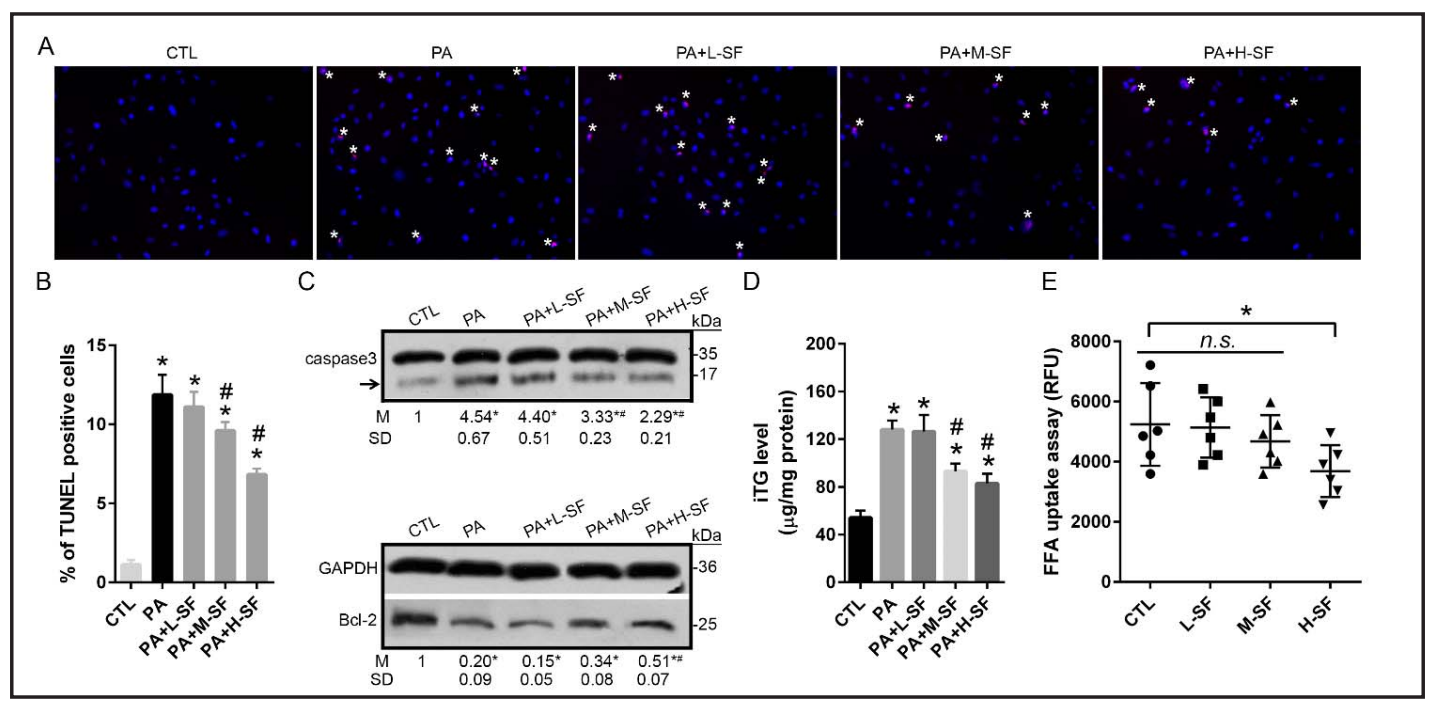

Fig. 2. ShenFu preparation shows a protective effect on PA-induced AML12 injury. AML12 cells were pretreated for $2 \mathrm{~h}$ with three different doses of SF preparation (L-SF: low, $25 \mu \mathrm{l} / \mathrm{ml}$; M-SF: moderate, $50 \mu \mathrm{l} / \mathrm{ml}$; and H-SF: high, $100 \mu \mathrm{l} / \mathrm{ml}$ ), followed by addition of $0.4 \mathrm{mM}$ of PA in the presence of SF preparation for 24 h. Non-treated cells were used as controls (CTL). (A) Apoptotic cells indicated by asterisk were revealed in red color using TUNEL assay. Magnification: 20x. (B) The percentage of apoptotic cells relative to total cells marked by blue nuclear stain was calculated, and compared between different groups. The data is presented as the means \pm S.D. $N=3 .{ }^{*} \mathrm{P}<0.05$ vs. CTL, ${ }^{\#} \mathrm{P}<0.05$ vs. PA. (C) Total cellular protein was extracted and immunoblot assay was performed to assess the levels of caspase 3 and Bcl-2. The cleaved caspase 3 was indicated by the arrow. The ratios of cleaved caspase 3 to total caspase 3 and the relative Bcl-2 to GAPDH was calculated and compared. The data is presented as the means \pm S.D. $\mathrm{N}=3$. ${ }^{*} \mathrm{P}<0.05$ vs. CTL, ${ }^{\#} \mathrm{P}<0.05$ vs. PA. (D) Intracellular triglyceride (iTG) level was measured using Triglyceride Colorimetric Assay. The data is presented as the means \pm S.D. $\mathrm{N}=3$. ${ }^{*} \mathrm{P}<0.05$ vs. CTL, ${ }^{\#} \mathrm{P}<0.05$ vs. PA. (E) AML12 cells were grown for $24 \mathrm{~h}$ in SF preparation containing media, and FFA uptake assay was then performed. Normal culture medium was used as the control. The data are presented as the means \pm S.D. $N=6 .{ }^{*} \mathrm{P}<0.05$ vs. CTL, n.s.: non-significance.

treatment (Fig. 1A, B). In addition, the level of iTG was assessed in PA-treated cells. Relative to control, the production of iTG dose-dependently increased following PA treatment (Fig. 
Fig. 3. ShenFu preparation prevents cytokine production in PA-treated AML12 cells. AML12 cells were pretreated for $2 \mathrm{~h}$ with ShenFu (SF) preparation (100 $\mu \mathrm{l} / \mathrm{ml}$ ), and then treated with $0.4 \mathrm{mM}$ of PA for $24 \mathrm{~h}$ in the presence of SF preparation. Non-treated cells were used as

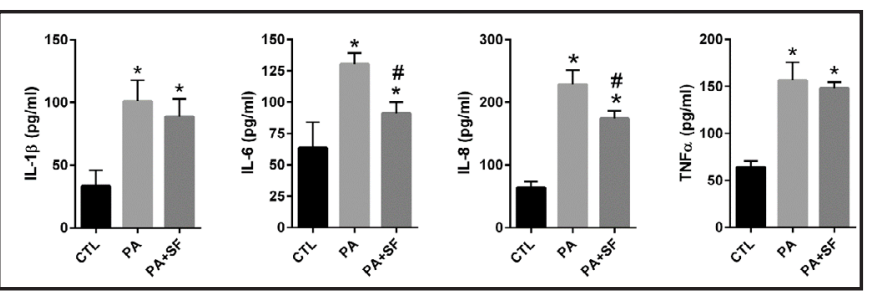
controls (CTL). Cell culture media were collected and centrifuged at 2,500 rpm for $10 \mathrm{~min}$ at $4^{\circ} \mathrm{C}$. The level of cytokines IL-1 $\beta$ (A), IL-6 (B), IL-8 (C), and TNF $\alpha$ (D) in supernatant was measured using ELISA kit. The data is presented as the means \pm S.D. $N=$ 3. ${ }^{*} \mathrm{P}<0.05$ vs. CTL; ${ }^{"} \mathrm{P}<0.05$ vs. PA.

Fig. 4. Mitochondrial dysfunction is prevented by ShenFu preparation in PA-treated AML12 cells. (A - E) AML12 cells were pretreated for $2 \mathrm{~h}$ with three different doses of SF preparation (L-SF: low, $25 \mu \mathrm{l} /$ $\mathrm{ml}$; M-SF: moderate, $50 \mu \mathrm{l} / \mathrm{ml}$; and H-SF: high, $100 \mu \mathrm{l} / \mathrm{ml}$ ), and then treated with $0.4 \mathrm{mM}$ of PA for 24 $\mathrm{h}$ in the presence of SF preparation. Non-treated cells were used as controls (CTL). Mitochondrial membrane potential (MMP) level was assessed using JC-1 assay (A). Total cellular protein $(\mathrm{T})$ as well as cytosolic (C), mitochondrial (M) and nuclear $(\mathrm{N})$ containing fractions were isolated from AML12 cells, and verified by using immunoblot assays with specific fractional markers (B). The abundance of Nox4 was assessed both in mitochondrial fraction (Mit) and in whole cell lysates (C). The abun-

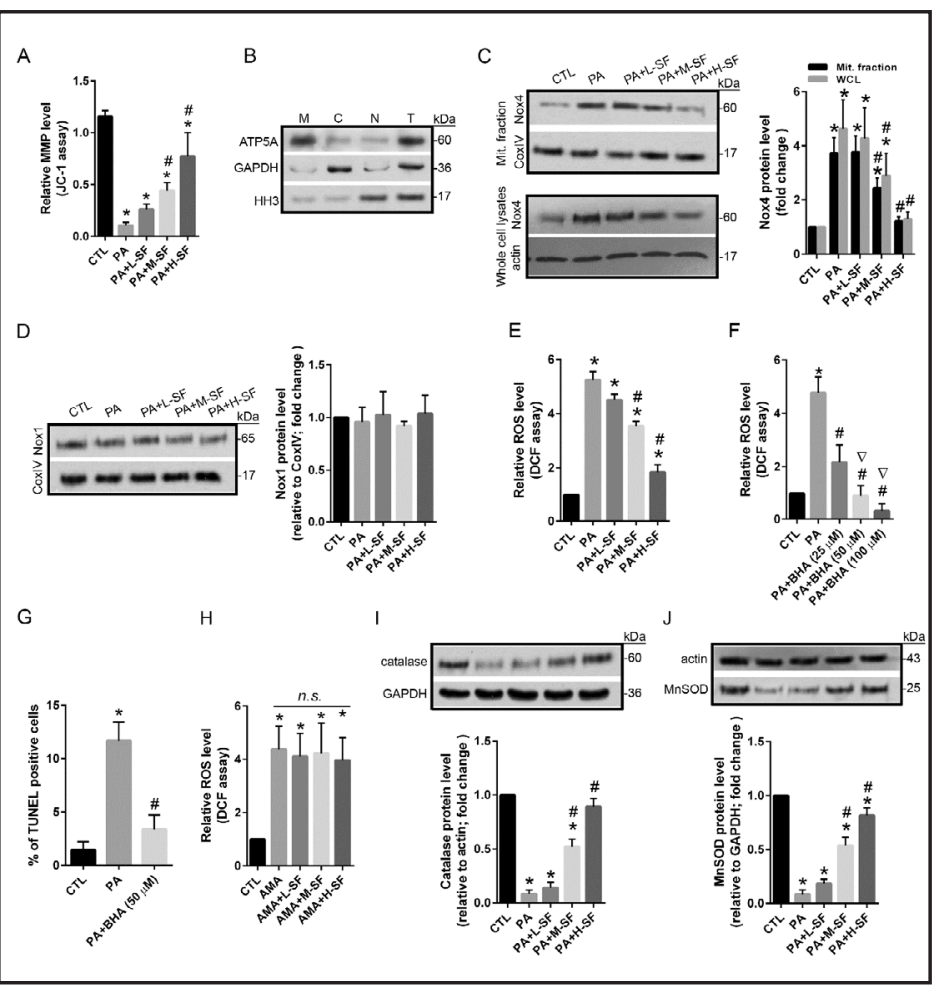
dance of Nox1 was evaluated in isolated mitochondrial fractions (D). Relative cellular reactive oxygen species (ROS) levels were analyzed using DCF assay (E). (F, G) AML12 cells were treated for $24 \mathrm{~h}$ with PA $(0.4 \mathrm{mM})$ in the presence or absence of butylated hydroxyanisole (BHA), a ROS scavenger. ROS levels and cellular apoptosis was assessed using DCF assay and TUNEL assays, respectively. (H) AML12 cells were treated for 30 min with mitochondrial respiration chain inhibitor antimycin A (AMA) $(2.5 \mu \mathrm{M})$ in the presence or absence of SF preparation. ROS levels were quantitated using DCF assays. (I, J) AML12 cells were pretreated for $2 \mathrm{~h}$ with three different doses of SF preparation, and then treated with $0.4 \mathrm{mM}$ of PA for $24 \mathrm{~h}$ in the presence of SF preparation. The levels of catalase and MnSOD were quantitated using immunoblot assays. The data is presented as the means \pm S.D. $\mathrm{N}=3 .{ }^{*} \mathrm{P}<0.05$ vs. $\mathrm{CTL},{ }^{*} \mathrm{P}<0.05$ vs. $\mathrm{PA},{ }^{\triangle} \mathrm{P}<0.05$ vs. $\mathrm{PA}+\mathrm{BHA}(25 \mu \mathrm{M})$, n.s.: non-significance. HH3: histone $\mathrm{H} 3$.

1C). Previously, increased iTG level within the same range was also reported in PA-treated HepG2 cell [16].

To reveal if SF preparation has a protective role in PA-induced AML12 injury, we applied low, moderate, and high doses of SF preparation to AML12 cells treated with $0.4 \mathrm{mM}$ of PA for $24 \mathrm{~h}$. TUNEL assay shows that PA-induced apoptosis was significantly decreased by both moderate and high doses of SF preparation (Fig. 2A, B), indicating that SF preparation protects 


\section{Cellular Physiology Cell Physiol Biochem 2018:45:1617-1630 \\ \begin{tabular}{l|l|l} 
and Biochemistry Published online: February 26, 2018 & $\begin{array}{l}\text { (c) } 2018 \text { The Author(s). Published by S. Karger AG, Basel } \\
\text { www.karger.com/cpb }\end{array}$ \\
\hline
\end{tabular} \\ Ji et al.: The Protective Role of ShenFu Preparation in PA-Induced AML12 Cell Injury}

AML12 cells from PA-mediated apoptosis. Caspase 3, a frequently activated death protease, is required for some typical hallmarks of programmed cell death and/or apoptosis [9]. The activated/cleaved caspase 3 level was attained using immunoblot assay to further verify the protective role of SF preparation in PA-damaged AML12 cell. Compared to controls, the level of the cleaved form of caspase 3 was dramatically increased in PA-treated cells, whereas it was significantly inhibited by both moderate and high doses of SF preparation (Fig. 2C). $\mathrm{Bcl}-2$ is localized to the outer membrane of mitochondria, where it plays an important role in promoting cellular survival and inhibiting the actions of pro-apoptotic proteins [17]. Our results show that the abundance of Bcl-2 protein was decreased significantly in PA-treated cells in comparison with controls, which was prevented by high dose of SF preparation (Fig. 2C). Moreover, increased iTG levels caused by PA was significantly prevented by both moderate and high doses of SF preparation (Fig. 2D). These findings demonstrate that the application of SF preparation decreases PA-mediated AML12 injury, presenting with reduction of apoptosis and iTG levels. In this study, we also investigated if SF preparation could influence PA uptake. FFA uptake assay was then performed in AML12 cell in the presence or absence of SF preparation. Our data shows that high concentration of SF preparation decreased FITCconjugated FFA uptake, whereas uptake of FFA showed no difference between non-treated cells and the cells treated with either low or moderate concentration of SF preparation (Fig. 2E).

ShenFu preparation decreases inflammatory cytokines production in PA-treated AML12 cells

Inflammation due to the over-production of pro-inflammatory cytokines plays a critical role in the development of hepatocytes injury [7]. We explored the effect of high dose of SF preparation on cytokine levels in cultured AML12 cells treated with $0.4 \mathrm{mM}$ of PA for $24 \mathrm{~h}$. As compared with controls, the level of IL-1 $\beta$, IL-6, IL- 8 and TNF $\alpha$ was remarkably increased in PA-treated cells (Fig. 3A - D). Nevertheless, only PA-induced overproduction of IL-6 and IL-8 was decreased by the application of SF preparation (Fig. 3B, C).

PA-induced mitochondrial dysfunction is alleviated by ShenFu preparation treatment in AML12 cells

Mitochondrial function is assessed using JC-1 assay for the mitochondrial membrane potential (MMP) level [11]. In comparison with controls, MMP levels were decreased significantly in AML12 cells treated with $0.4 \mathrm{mM}$ of PA for $24 \mathrm{~h}$, indicative of mitochondrial dysfunction. PA-induced reduction of MMP levels was prevented by both moderate and high doses of SF preparation (Fig. 4A). To analyze the alteration of mitochondrial proteins, different cellular fractions were isolated and verified by using the specific markers for mitochondrial, cytosolic, nuclear and total cellular proteins, respectively (Fig. 4B). Immunoblot assay shows that compared to controls, the abundance of Nox4 both in the whole cell lysates and in the mitochondrial fraction was significantly increased, which was prevented by both moderate and high doses of SF preparation (Fig. 4C). In our study, the level of mitochondrial NoxI showed no significant change in AML12 cells treated with PA alone or in combination with SF preparation (Fig. 4D).

Routinely, mitochondrial dysfunction, particularly the increased Nox4, leads to oxidative stress [18]. Here, the reactive oxygen species (ROS) level was investigated using DCF assay. Our results show that in comparison with controls, the ROS level was increased dramatically in PA-treated AML12 cells, which was prevented by both moderate and high doses of SF preparation (Fig. 4E). To verify the role of oxidative stress in PA-induced AML12 apoptosis, we depleted the production of ROS by an ROS scavenger, BHA in PA-treated cells (Fig. 4F), and found that PA-induced apoptosis was dramatically decreased by BHA (Fig. 4G), indicating that oxidative stress may be a predominant pathway in induction of apoptosis in PA-treated AML12 cells. We further tested if SF preparation decreased PA-induced AML12 injury directly as an antioxidant. The application of AMA, a mitochondrial complex III inhibitor, significantly increased ROS level, which was not affected by SF preparation (Fig. 4H). The downstream 
Fig. 5. Increased Nox4 is responsible for PA-induced AML12 apoptosis. AML12 cells were pretreated for $1 \mathrm{~h}$ with a novel Nox1/Nox4 inhibitor GKT137381, and then treated with PA $(0.4 \mathrm{mM})$ in the presence of GKT137381. Non-treated cells were used as controls (CTL). (A) Relative

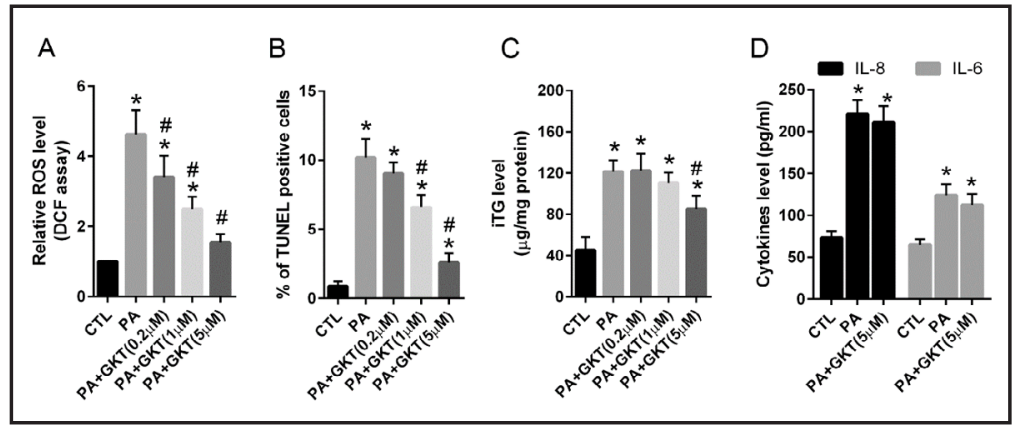
cellular reactive oxygen species (ROS) levels were analyzed using DCF assays. (B) Apoptosis was evaluated using TUNEL assay, and the percentage of apoptotic cells relative to total cells was compared. (C) Intracellular triglyceride (iTG) levels were measured using Triglyceride Colorimetric Assay. (D). Cell culture media was collected and centrifuged at 2,500 rpm for $10 \mathrm{~min}$ at $4^{\circ} \mathrm{C}$. The levels of cytokines IL- 6 and IL-8 in supernatant were measured using ELISA kit. The data is presented as the means \pm S.D. $\mathrm{N}=3$. ${ }^{*} \mathrm{P}<0.05$ vs. CTL, ${ }^{"} \mathrm{P}<0.05$ vs. PA.

Fig. 6. Activation of JNK/Nox4 signaling is prevented by ShenFu preparation in PA-treated AML12 cells. (A) AML12 cells were pretreated for $2 \mathrm{~h}$ with ShenFu preparation $(100 \mu \mathrm{l} / \mathrm{ml})$, and then treated with $0.4 \mathrm{mM}$ of PA for different time periods in the presence of SF preparation. Total cellular protein was extracted, and the phosphorylated JNK level was assessed using immunoblot assay. (B) AML12 cells were pretreated for $1 \mathrm{~h}$ with a selective JNK inhibitor SP600125 (10 $\mu \mathrm{M})$, and then treated with $0.4 \mathrm{mM}$ of PA for indicated time periods in the presence of SP600125. The phosphorylated JNK level was assessed using immunoblot assay. (C, D) AML12 cells were pretreated for $1 \mathrm{~h}$ with SP600125 $(10 \mu \mathrm{M})$, and then treated with 0.4 $\mathrm{mM}$ of PA for $24 \mathrm{~h}$ in the presence of SP600125. Effect of SP600125 on cellular apoptosis was analyzed in PA-treated AML12 cells, and the protein level of Nox4 was measured using immunoblot assay. (E) AML12 cells were treated for the indicated time points with PA $(0.4 \mathrm{mM})$ in the presence or absence of a ROS scavenger, butylated hydroxyanisole (BHA, $50 \mu \mathrm{M})$. Total cellular protein was extracted, and phospho-JNK levels were measured using immunoblot assay. (F) AML12 cells were treated for $24 \mathrm{~h}$ with PA $(0.4 \mathrm{mM})$ in the presence or absence of BHA $(50 \mu \mathrm{M})$, and Nox4 protein levels were assessed using immunoblot assay. The data is presented as the means \pm S.D. $N=3$. ${ }^{*} \mathrm{P}<0.05$ vs. 0 min or $\mathrm{CTL},{ }^{*} \mathrm{P}<0.05$ vs. $\mathrm{PA},{ }^{\$} \mathrm{P}<0.05$ with comparisons indicated by lines.

signal of ROS was further assessed in PA and SF preparation treated cells. It is well known that catalase and MnSOD are key enzymatic antioxidants, protecting cells from injuries induced by mitochondrial and peroxisomal ROS, respectively [19]. Consistently, the level of MnSOD and catalase decreased remarkably following PA treatment, which was prevented by both moderate and high doses of SF preparation (Fig. 4I, J).

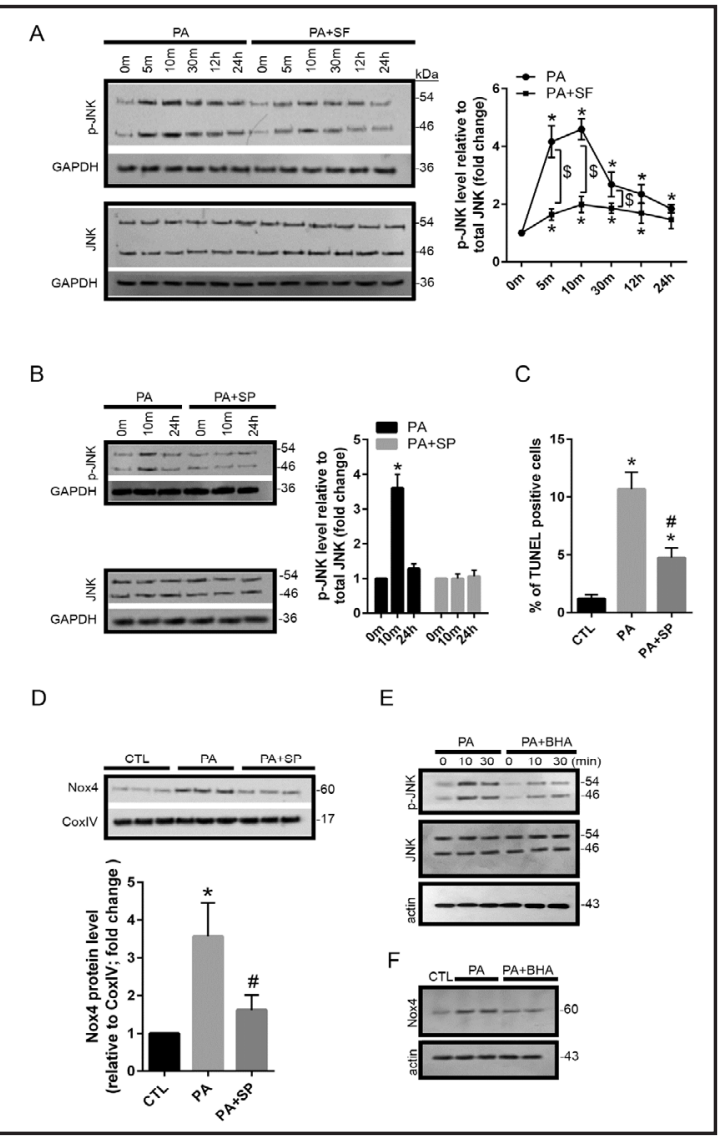

KARGER 
ShenFu preparation protects AML12 cells from PA-induced apoptosis through inhibition of JNK-Nox4 pathway

To further reveal the role of Nox4 in PA-induced AML12 injury, GKT137381, a novel Nox1/ Nox4 inhibitor, was applied since Nox1 did not show any change in our study. Increased ROS level by PA was significantly prevented by GKT137381 in a dose-dependent manner (Fig. 5A). Importantly, the application of GKT137381 dose-dependently decreased the percentage of PA-induced apoptosis in cultured AML12 cells (Fig. 5B). Unexpectedly, GKT137381 showed no significant effect on the production of iTG and the level of IL-8 and IL-6 in PA-treated cells (Fig. 5C, D). Our data show that $5 \mu \mathrm{M}$ of GKT137381 slightly prevented PA-induced increase

Fig. 7. Activation of JNK/ NFKB mediated increase of cytokines and intracellular triglyceride levels is prevented by ShenFu preparation in PA-treated AML12 cells. (A, B) AML12 cells were pretreated for $1 \mathrm{~h}$ with a selective JNK inhibitor SP600125 $(10 \mu \mathrm{M})$, and then treated with PA $(0.4 \mathrm{mM})$ in the presence of SP600125. Non-treated cells were used as controls (CTL). Cell culture media was collected and centrifuged. The levels of cytokines IL-6 and IL-8 in supernatant were measured using ELISA kit (A). Intracellular triglyceride (iTG) levels were measured using Triglyceride Colorimetric Assay (B). The data is presented as the means \pm S.D. $N=3 .{ }^{*} \mathrm{P}<0.05$ vs. CTL, ${ }^{\#} \mathrm{P}<0.05$ vs. PA. (C) AML12 cells were pretreated for 2 $\mathrm{h}$ with SF preparation (100 $\mu \mathrm{l} / \mathrm{ml})$, and then treated with $0.4 \mathrm{mM}$ of PA for different time periods in the presence of SF preparation.

Cytosolic and nuclear proteins were extracted, respectively. The abundance of cytosolic I $\kappa \mathrm{B} \alpha$ and nuclear $\mathrm{NF \kappa B} / \mathrm{p} 65$ subunits was assessed using immunoblot assay. The data is presented as the means \pm S.D. $\mathrm{N}=3$. ${ }^{*} \mathrm{P}<0.05$ vs. $0 \mathrm{~min},{ }^{\#} \mathrm{P}<0.05$ vs. $0 \mathrm{~min},{ }^{\$} \mathrm{P}<0.05 \mathrm{PA}+\mathrm{SF}$ vs. PA. (D) AML12 cells were pretreated for $1 \mathrm{~h}$ with an I $\mathrm{B}$ degradation inhibitor BAY 11-7082 $(10 \mu \mathrm{M})$, and then treated with 0.4 mM of PA for 10 min and 24 $h$ in the presence of BAY 11-7082. The abundance of cytosolic $\mathrm{I} \kappa \mathrm{B} \alpha$ and nuclear NF $\mathrm{B} / \mathrm{p} 65$ subunits was assessed using immunoblot assay. The data is presented as the means \pm S.D. $N=3$. ${ }^{*} \mathrm{P}<0.05$ vs. 0 min. $(E-H)$ AML12 cells were pretreated for $1 \mathrm{~h}$ with BAY 11-7082 $(10 \mu \mathrm{M})$, and then treated with $0.4 \mathrm{mM}$ of PA for 24 $\mathrm{h}$ in the presence of BAY 11-7082. Cell culture media was collected and centrifuged. The levels of cytokines IL-6 and IL-8 in supernatant were measured using ELISA kit (E). Intracellular triglyceride (iTG) level was measured using Triglyceride Colorimetric Assay (F). Apoptosis was evaluated using TUNEL assay (G). Relative cellular reactive oxygen species (ROS) level was analyzed using DCF assay (H). The data is presented as the means \pm S.D. $N=3 .{ }^{*} \mathrm{P}<0.05$ vs. CTL, ${ }^{\#} \mathrm{P}<0.05$ vs. PA.

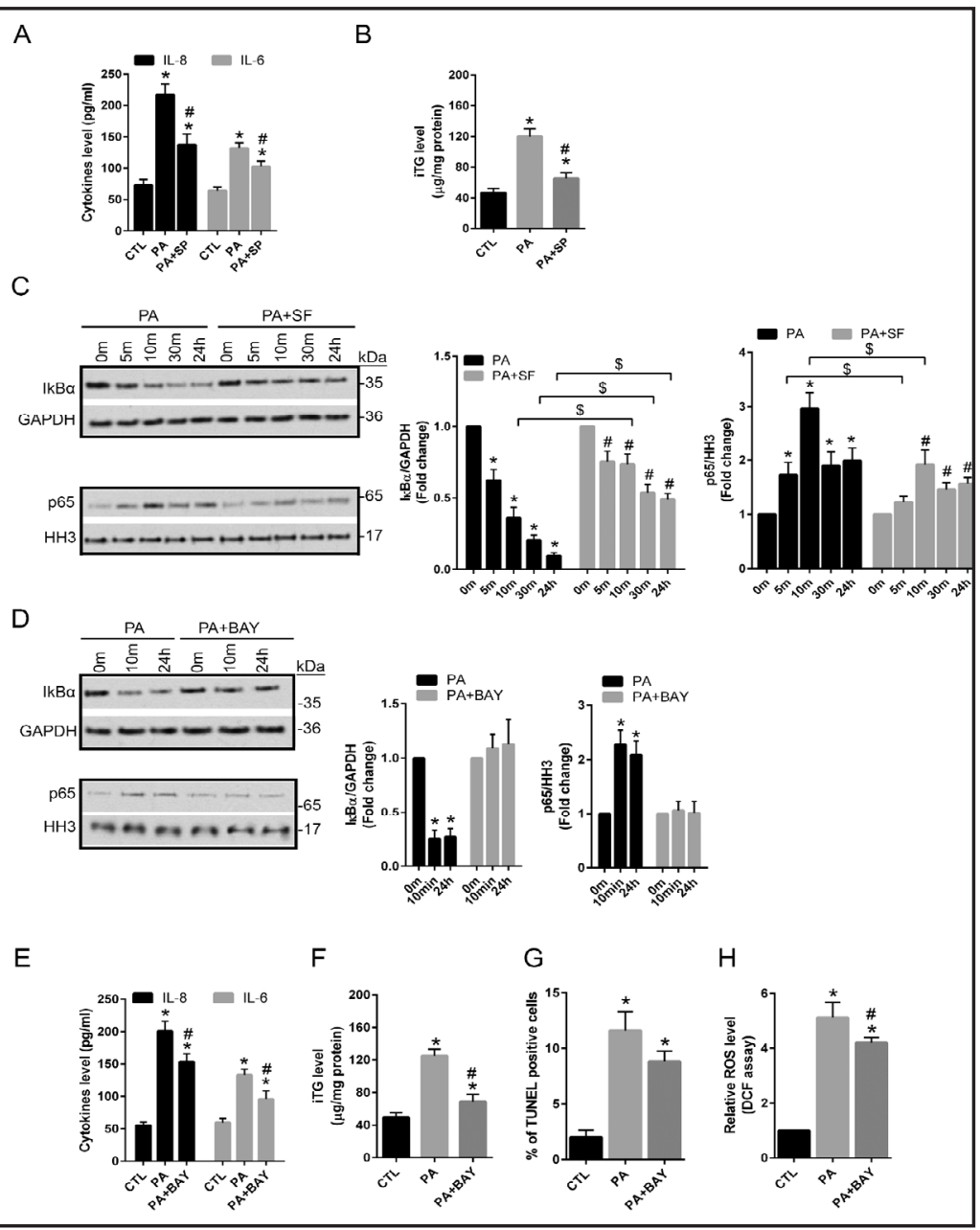




\section{Cellular Physiology Cell Physiol Biochem 2018;45:1617-1630 \\ \begin{tabular}{ll|l} 
DOI: 10.1159/000487728 & (0) 2018 The Author(s). Published by S. Karger AG, Basel \\
www.karger.com/cpb
\end{tabular} \\ Ji et al.: The Protective Role of ShenFu Preparation in PA-Induced AML12 Cell Injury}

of iTG levels (Fig. 5C). These results imply that increased Nox4-mediated mitochondrial dysfunction and oxidative stress are mainly involved in PA-induced AML12 apoptosis.

It was reported that the activation of JNK is responsible for Nox4 induction in human breast stromal cells [20]. Firstly, a time-dependent increase of phosphorylated JNK was rapidly detected after $5 \mathrm{~min}$ peaking at $10 \mathrm{~min}$ and persisting to $24 \mathrm{~h}$ in $0.4 \mathrm{mM}$ of PA treated AML12 cells, which was significantly prevented by the application of SF preparation (Fig. 6A). To investigate the role of JNK signaling in PA-treated cells, the activity of JNK was prohibited by SP600125, a selective JNK inhibitor (Fig. 6B). Moreover, PA-induced apoptosis was significantly decreased by SP600125 (Fig. 6C). The application of SP600125 also prevented PA-induced increase of Nox4 in cultured AML12 cells (Fig. 6D). These results indicate that SF preparation may protect AML12 cells from PA-induced apoptosis through inhibition of JNK/Nox4-mediated mitochondrial dysfunction and ROS production. We also explored the role of oxidative stress on the activity of the JNK pathway by depletion of ROS with BHA in PA-treated AML12 cell. Unexpectedly, in PA-treated cells, increased phospho-JNK levels were remarkably inhibited by BHA (Fig. 6E). BHA also prevented elevation of Nox4 induced by PA (Fig. 6F).

ShenFu preparation decreases PA-induced intracellular triglyceride and cytokines production through inhibition of JNK-NFKB pathway

The effect of JNK pathway on iTG and cytokine levels was investigated by applying JNK inhibitor SP600125 to PA-treated AML12 cells. PA-induced increase of IL-8 and IL-6 was significantly prevented by SP600125 (Fig. 7A). Similarly, increased iTG by PA was prevented by SP600125 (Fig. 7B). It is well known that NFKB plays a critical role in cytokines production in various types of cells [20]. Firstly, we evaluated the level of cytosolic IкB $\alpha$ in PA-treated AML12 cells since degradation of IкB $\alpha$ promotes translocation of the NFKB/ p65 subunit from the cytoplasm to the nucleus where $\mathrm{NF \kappa B} / \mathrm{p} 65$ increases transcription as a transcriptional factor [21]. Immunoblot assay shows a time-dependent reduction of cytosolic IкB $\alpha$ after 5 min persisting to $24 \mathrm{~h}$ following PA treatment (Fig. 7C). Consistently, a time-dependent increase of nuclear $\mathrm{NF \kappa B} / \mathrm{p} 65$ was detected in PA-treated cells (Fig. 7C).

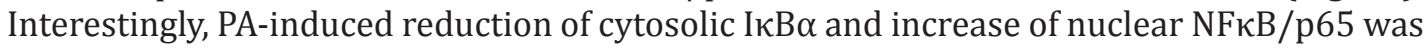
dramatically prevented by the application of SF preparation (Fig. 7C).

To further investigate the role of $\mathrm{NF \kappa B}$ signaling, nuclear translocation of NFKB/p65 was blocked using BAY11-7082, a potent IкB degradation inhibitor (Fig. 7D). The application of BAY11-7082 prevented an increase of IL-8 and IL-6 in PA-treated AML12 cells (Fig. 7E). Increased iTG level by PA was also prevented by BAY11-7082 (Fig. 7F). Nevertheless, the application of BAY11-7082 showed no significant effect on PA-mediated apoptosis (Fig. 7G). ROS levels were slightly decreased by BAT11-7082 in PA-treated cells (Fig. 7H). Therefore, these results indicate that SF preparation may decrease PA-induced cytokine and iTG production mainly through inhibition of JNK-mediated nuclear translocation of the NFKB/ p65 subunit.

\section{Discussion}

Hepatocyte injury induced by PA, a common NASH model, is primarily used to investigate the molecular mechanisms by which hepatocytes are damaged and hepatic steatosis develops. As previously reported $[6,10,11]$, we reproduced this model in cultured murine hepatic AML12 cells, and investigated if the traditional Chinese medicine SF preparation has a protective role in this model.

PA increased the level of activated caspase 3 , a critical caspase protein that plays a key role in induction of apoptosis both by extrinsic (death ligand) and intrinsic (mitochondrial) pathways. Induction of apoptosis was also detected in PA-treated cells. It was reported that SF preparation has obvious protective effects on cardiomyocytes against hypoxia/ reoxygenation-induced apoptosis probably through inhibition of Bcl-2 downregulation 
and sequential activation of caspase 3 [15]. In our study, the application of SF preparation dramatically suppressed PA-mediated cellular apoptosis. Increased caspase 3 activity and reduced Bcl-2 levels by PA were prevented in the presence of SF preparation. Some investigations demonstrated that lipid accumulation induced lipotoxicity involved FFAinduced hepatocytes injury, another cellular hepatic steatosis model [22]. We found that PA significantly increased iTG content, which was prevented by SF preparation. In addition, we detected overproduction of pro-inflammatory cytokines IL-6, IL-8, TNF $\alpha$, and IL-1 $\beta$ in PAtreated cells. Nevertheless, addition of SF preparation only decreased the levels of IL- 6 and IL-8 in PA-treated cells. In FFA-treated HepG2 cells, the level of IL-6, TNF $\alpha$, and IL-1 $\beta$ was also increased [23]. It was reported that the serum levels of IL-8 and TNF $\alpha$ were significantly higher in NASH patients than in healthy controls [24]. Thus, cytokine-mediated inflammatory responses may play an important role in hepatocyte injury and the development of NASH. Overall, our findings suggest that SF preparation has the ability to decrease PA-induced AML12 injury. However, further studies should be done to determine whether or not SF preparation could prevent lipotoxicity by blocking fatty acid uptake. Our results show that only high concentrations of SF preparation decreased FFA uptake in AML12 cells, implying that inhibition of FFA uptake may not be the major role of SF preparation in preventing hepatocyte injury.

Apoptosis occurs frequently in NASH and is associated with the progression of liver fibrosis [8]. Nox4, a member of the NOX family of NADPH oxidases, is responsible for the production of large amounts of ROS [20]. It was reported that Nox4-dependent ROS modulation can induce apoptosis in high Nox4-expressing cancer cells [18]. In our study, increased ROS was detected in PA-treated AML12 cells. Depletion of ROS by BHA, a ROS scavenger, dramatically blocked PA-induced apoptosis, suggesting that ROS represent the main inducers of necrotic cell death induced by PA in AML12 cells. We isolated different cellular fractions including mitochondrial, cytosolic and nuclear. Immunoblot assay shows that mitochondrial Nox4 abundance increased significantly in PA-treated cells, accompanied by the reduction of MMP levels and elevation of ROS production. Nox4 mRNA level was also upregulated in PA-treated HepG2 cell [25]. In the liver tissue of obsess mice, TGF $\beta$ is increased, leading to upregulation of Nox4 [26, 27]. Reduced MMP and elevated ROS levels were also described in treatment of primary rat hepatocytes with PA [10]. In our study, we further assessed the level of MnSOD and catalase, which are important enzymes in protecting the cell from oxidative damage by ROS [19]. We found that MnSOD and catalase protein levels were reduced remarkably by PA treatment. Furthermore, inhibition of Nox4 by GKT137381 significantly decreased ROS and apoptosis in PA-treated cells, while showing no significant influence on the iTG and cytokine levels. These results indicate that increased Nox4 by PA is only related to mitochondrial dysfunction that is responsible for the increase of ROS and apoptosis. Interestingly, addition of SF preparation prevented reduction of both MMP and MnSOD/catalase levels, and inhibited increase of Nox4. The beneficial role of SF preparation against PA-induced AML12 injury may be achieved through downregulation of Nox4 expression.

NFKB is a protein complex that controls transcription of DNA, cytokine production and cell survival [21]. Abnormal regulation of NFKB signaling has been linked to the occurrence and development of cancer, inflammatory and autoimmune diseases. In PA-treated AML12 cells, the NFkB/p65 subunit was translocated to nuclei which accompanied a decrease

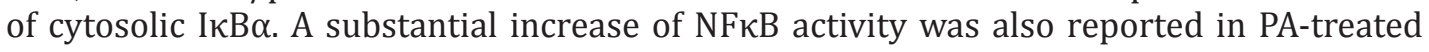

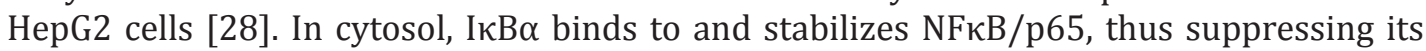
nuclear translocation [21]. We applied an IкB degradation inhibitor, BAY11-7082, that efficiently prevented nuclear translocation of $\mathrm{NF \kappa B} / \mathrm{p} 65$. We found that NFKB inhibition also suppressed PA-induced increase of ITG and cytokines IL- 6 and IL-8, while showing no influence on apoptosis and ROS. These findings suggest that NFkB signaling plays a crucial role in PA-mediated overproduction of iTG and cytokines. SF preparation protected rat liver grafts against ischemia-reperfusion injury, possibly by decreasing the level of TNF $\alpha$ and nuclear NFкB [29]. In PA-treated AML12 cells, addition of SF preparation also inhibited 


\section{Cellular Physiology Cell Physiol Biochem 2018;45:1617-1630

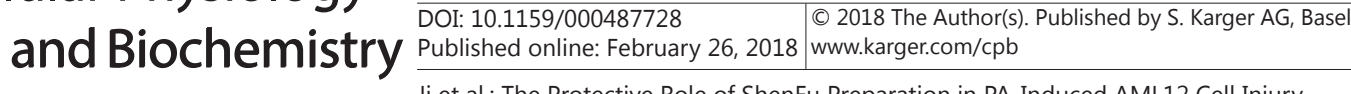

activation of NFkB signaling, presenting with reduction of nuclear NFkB/p65 and inhibition of cytosolic IkB $\alpha$ degradation.

It was found that activation of JNK signaling is responsible for Nox4 induction in human breast cancer cells [20]. It was also reported that in both squamous cell carcinoma cells and melanoma tumor cells, chloroquine enhanced $\mathrm{NF \kappa B}$ activation leading to increased expression of its target genes such as hypoxia-inducible factor (HIF-1 $\alpha$ ) and IL-8 through JNK signaling [30]. Moreover, PA-induced IL-8 production was attenuated by inhibition of JNK and NFKB in HepG2 cells [28]. In the current study, time-dependent over-activation of JNK was detected in PA-treated AML12 cells, and inhibition of JNK by SP600125 substantially suppressed PA-mediated increase of Nox4. SP600125 also decreased apoptosis and the level of iTG and cytokines IL-8 and IL-6. Therefore, our findings imply that Nox4 is responsible for increasing ROS potentially via JNK signaling. Conversely, increasing amount of evidence suggests that increased ROS could enhance JNK activation [31]. We thus tested the effect of ROS on JNK activity in our model, and found that inhibition of ROS by BHA decreased the level of phospho-JNK and Nox4 protein, indicating that ROS may mediate feedback activation of the JNK pathway in PA-treated cells.

Of note, the application of SF preparation suppressed PA-induced over-activation of JNK and nuclear translocation of NFKB. To confirm the protective role of SF preparation in PA-induced AML12 injuries by inhibition of JNK pathway, it would be better to perform experiments in JNK deficient hepatocytes. Additionally, it was reported that activation of p38MAPK also contributed to NFKB activation and mitochondrial protein Cox-2 upregulation in PA-treated AML12 cells [32]. In rats, SF preparation protected hepatic tissue from ischemia-reperfusion injury by decreasing the ratio of thromboxane A (2) and prostacyclin, and increasing the activities of $\mathrm{Na}^{+} / \mathrm{K}^{+}$-ATPase and $\mathrm{Ca}^{+} / \mathrm{Mg}^{+}$-ATPase [33]. To further reveal and verify the protective mechanism of SF preparation, the role of JNK and other potential signaling pathways needs be further evaluated in future studies. Our current findings suggest that SF preparation may attenuate PA-induced hepatic apoptosis, lipogenesis and excessive cytokine production at least partially by inhibition of JNK/Nox4 and JNK/NFKB pathways, respectively.

Finally, we tested if SF preparation directly acted as an antioxidant in protecting PAinduced AML12 injury. We applied AMA, a mitochondrial complex III inhibitor that can aberrantly increase superoxide production [34]. As previously reported [35], treatment of AML12 with $2.5 \mu \mathrm{M}$ AMA significantly increased ROS level. Nevertheless, addition of SF preparation showed no obvious effect on AMA-mediated ROS production. This result may be able to exclude the role of SF preparation as a direct antioxidant.

\section{Conclusion}

Taken together, we provide new molecular insights into the protective mechanism of SF preparation on hepatic cell injury. Nevertheless, it should be noted that commercial SF preparation was used in this study. It has been recognized that aconitum alkaloids and ginsenosides are the main active components in SF preparation $[13,14]$. Yang et al. identified 23 trace diterpene alkaloids, 19 ginseng saponins, one panaxytriol, and one 5-hydroxymethylfurfural in SF preparation, and quantitated that the total concentrations of saponins and alkaloids were about $676-742 \mu \mathrm{g} / \mathrm{mL}$ and $3-7 \mu \mathrm{g} / \mathrm{mL}$ in five batches of SF preparation samples, respectively [13]. The limitation of our work might be that we did not evaluate the effect of individual components of SF preparation on PA-induced hepatocyte injury. This is a common issue for most traditional Chinese herb medicine. In addition, we are planning to do some in vivo studies to investigate the correlation of JNK/Nox4 and JNK/ NFKB pathways in rat or mouse NASH models treated with SF preparation. Thus, we may determine whether SF preparation could be a good therapeutic strategy for the treatment of hepatic cell injury in NASH.

\section{KARGER}




\section{Cellular Physiology Cell Physiol Biochem 2018;45:1617-1630 \begin{tabular}{ll|l} 
and Biochemistry Published online: February 26, 2018 & $\begin{array}{l}\text { (c) } 2018 \text { The Author(s). Published by S. Karger AG, Basel } \\
\text { www.karger.com/cpb }\end{array}$ \\
\hline
\end{tabular} \\ Ji et al.: The Protective Role of ShenFu Preparation in PA-Induced AML12 Cell Injury}

\section{Acknowledgements}

This work was supported by the grants from the National Nature Science Foundation of China (No. 81673969 to Li-Li Chi) and the Key Program of Shandong Province Nature Science Foundation (ZR2014HZ005 to Fan Su).

\section{Disclosure Statement}

The authors declare that there are no conflicts of interest regarding the publication of this paper.

\section{References}

1 Benedict M, Zhang X: Non-alcoholic fatty liver disease: An expanded review. World J Hepatol 2017; 9:715732 .

- Wong VW, Chitturi S, Wong GL, Yu J, Chan HL, Farrell GC: Pathogenesis and novel treatment options for nonalcoholic steatohepatitis. Lancet Gastroenterol Hepatol 2016;1:56-67.

3 McCullough AJ: Pathophysiology of nonalcoholic steatohepatitis. J Clin Gastroenterol 2006;40:S17-S29.

4 Donnelly KL, Smith CI, Schwarzenberg SJ, Jessurun J, Boldt MD, Parks EJ: Sources of fatty acids stored in liver and secreted via lipoproteins in patients with nonalcoholic fatty liver disease. J Clin Invest 2005;115:1343-1351.

5 Puri P, Baillie RA, Wiest MM, Mirshahi F, Choudhury J, Cheung O, Sargeant C, Contos MJ, Sanyal AJ: A lipidomic analysis of nonalcoholic fatty liver disease. Hepatology 2007;46:1081-1090.

-6 Grishko V, Rachek L, Musiyenko S, Ledoux SP, Wilson GL: Involvement of mtDNA damage in free fatty acidinduced apoptosis. Free Radic Biol Med 2005;38:755-762.

7 Chakraborty JB, Oakley F, Walsh MJ: Mechanisms and biomarkers of apoptosis in liver disease and fibrosis. Int J Hepatol 2012;2012:648915.

8 Feldstein AE, Canbay A, Angulo P, Taniai M, Burgart LJ, Lindor KD, Gores GJ: Hepatocyte apoptosis and Fas expression are prominent features of human nonalcoholic steatohepatitis. Gastroenterology 2003;125:437-443.

-9 Vakifahmetoglu-Norberg H, Ouchida AT, Norberg E: The role of mitochondria in metabolism and cell death. Biochem Biophys Res Commun 2017;482:426-431.

10 Moravcová A, Červinková Z, Kučera O, Mezera V, Rychtrmoc D, Lotková H: The effect of oleic and palmitic acid on induction of steatosis and cytotoxicity on rat hepatocytes in primary culture. Physiol Res 2015;64:S627-S636.

11 Jun DW, Cho WK, Jun JH, Kwon HJ, Jang KS, Kim HJ, Jeon HJ, Lee KN, Lee HL, Lee OY, Yoon BC, Choi HS, Hahm JS, Lee MH: Prevention of free fatty acid-induced hepatic lipotoxicity by carnitine via reversal of mitochondrial dysfunction. Liver Int 2011;31:1315-1324.

-12 Chiu HC, Kovacs A, Ford DA, Hsu FF, Garcia R, Herrero P, Saffitz JE, Schaffer JE: A novel mouse model of lipotoxic cardiomyopathy. J Clin Investig 2001;107:813-822.

13 Yang H, Liu L, Gao W, Liu K, Qi LW, Li P: Direct and comprehensive analysis of ginsenosides and diterpene alkaloids in Shenfu injection by combinatory liquid chromatography-mass spectrometric techniques. J Pharm Biomed Anal 2014;92:13-21.

14 Li Y, Zhang X, Lin P, Qiu H, Wei J, Cao Y, Pan S, Walline J, Qian C, Shan Z, Yu X: Effects of Shenfu Injection in the Treatment of Septic Shock Patients: A Multicenter, Controlled, Randomized, Open-Label Trial. Evid Based Complement Alternat Med 2016;2016:2565169.

15 Wang YL, Wang CY, Zhang BJ, Zhang ZZ: Shenfu injection suppresses apoptosis by regulation of Bcl2 and caspase-3 during hypoxia/reoxygenation in neonatal rat cardiomyocytes in vitro. Mol Biol Rep 2009;36:365-370.

16 Hetherington AM, Sawyez CG, Zilberman E, Stoianov AM, Robson DL, Borradaile NM: Differential Lipotoxic Effects of Palmitate and Oleate in Activated Human Hepatic Stellate Cells and Epithelial Hepatoma Cells. Cell Physiol Biochem 2016;39:1648-1662. 


\section{Cellular Physiology Cell Physiol Biochem 2018;45:1617-1630

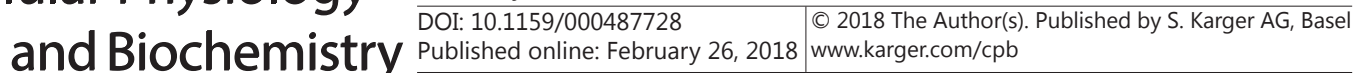

17 Gross A, Katz SG: Non-apoptotic functions of BCL-2 family proteins. Cell Death Differ 2017;24:1348-1358.

18 Zhu P, Tong BM, Wang R, Chen JP, Foo S, Chong HC, Wang XL, Ang GY, Chiba S, Tan NS: Nox4-dependent ROS modulation by amino endoperoxides to induce apoptosis in cancer cells. Cell Death Dis 2013;4:e552.

19 Rochette L, Zeller M, Cottin Y, Vergely C: Diabetes, oxidative stress and therapeutic strategies. Biochim Biophys Acta 2014;1840:2709-2729.

20 Tobar N, Toyos M, Urra C, Méndez N, Arancibia R, Smith PC, Martínez J: c-Jun N terminal kinase modulates NOX-4 derived ROS production and myofibroblasts differentiation in human breast stromal cells. BMC Cancer 2014;14:640.

-21 Ghosh S, Dass JF: Study of pathway cross-talk interactions with NF- $\kappa B$ leading to its activation via ubiquitination or phosphorylation: A brief review. Gene 2016;584:97-109.

22 Yao HR, Liu J, Plumeri D, Cao YB, He T, Lin L, Li Y, Jiang YY, Li J, Shang J: Lipotoxicity in HepG2 cells triggered by free fatty acids. Am J Transl Res 2011;3:284-291.

23 Liang H, Zhang L, Wang H, Tang J, Yang J, Wu C, Chen S: Inhibitory Effect of Gardenoside on Free Fatty AcidInduced Steatosis in HepG2 Hepatocytes. Int J Mol Sci 2015;16:27749-27756.

24 Bahcecioglu IH, Yalniz M, Ataseven H, Ilhan N, Ozercan IH, Seckin D, Sahin K: Levels of serum hyaluronic acid, TNF-alpha and IL-8 in patients with nonalcoholic steatohepatitis. Hepatogastroenterology 2005;52:1549-1553.

25 García-Ruiz I, Solís-Muñoz P, Fernández-Moreira D, Muñoz-Yagüe T, Solís-Herruzo JA: In vitro treatment of HepG2 cells with saturated fatty acids reproduces mitochondrial dysfunction found in nonalcoholic steatohepatitis. Dis Model Mech 2015;8:183-191.

-26 Carmona-Cuenca I, Herrera B, Ventura JJ, Roncero C, Fernández M, Fabregat I: TGF blocks NADPH oxidase activation by TGF-beta in fetal rat hepatocytes, impairing oxidative stress, and cell death. J Cell Physiol 2006;207:322-330.

-27 García-Ruiz I, Solís-Muñoz P, Fernández-Moreira D, Grau M, Colina F, Muñoz-Yagüe T, Solís-Herruzo JA: High-fat diet decreases activity of the oxidative phosphorylation complexes and causes nonalcoholic steatohepatitis in mice. Dis Model Mech 2014;7:1287-1296.

28 Joshi-Barve S, Barve SS, Amancherla K, Gobejishvili L, Hill D, Cave M, Hote P, McClain CJ: Palmitic acid induces production of proinflammatory cytokine interleukin-8 from hepatocytes. Hepatology 2007;46:823830.

29 Chen T, Cheng M, Yuan Z, Zhou S, Yu Z: Protective role of Shenfu on ischemia-reperfusion injury of rat liver grafts. Transplant Proc 2012;44:978-981.

-30 Yang S, Qiang L, Sample A, Shah P, He YY: NF- $\mathrm{BB}$ Signaling Activation Induced by Chloroquine Requires Autophagosome, p62 Protein, and c-Jun N-terminal Kinase (JNK) Signaling and Promotes Tumor Cell Resistance. J Biol Chem 2017;292:3379-3388.

31 Shen HM, Liu ZG: JNK signaling pathway is a key modulator in cell death mediated by reactive oxygen and nitrogen species. Free Radic Biol Med 2006;40:928-939.

-32 Park MJ, Kim DI, Choi JH, Heo YR, Park SH: New role of irisin in hepatocytes: The protective effect of hepatic steatosis in vitro. Cell Signal 2015;27:1831-1839.

-33 Peng SL, Gu X, Dai CL, Huang Y, Zhao Y: Effects of Shenfu injection on prostacyclin, thromboxane A2 and activities of ATPases in rats exposed to hepatic ischemia-reperfusion injury. Zhong Xi Yi Jie He Xue Bao 2007;5:427-431.

-34 Vankoningsloo S, De Pauw A, Houbion A, Tejerina S, Demazy C, de Longueville F, Bertholet V, Renard P, Remacle J, Holvoet P, Raes M, Arnould T: CREB activation induced by mitochondrial dysfunction triggers triglyceride accumulation in 3T3-L1 preadipocytes. J Cell Sci 2006;119:1266-1282.

-35 Kohli R, Pan X, Malladi P, Wainwright MS, Whitington PF: Mitochondrial reactive oxygen species signal hepatocyte steatosis by regulating the phosphatidylinositol 3-kinase cell survival pathway. J Biol Chem 2007;282:21327-21336. 